\title{
ISOLASI BAKTERI RESISTENSI MERKURI DARI LIMBAH PENAMBANGAN EMAS KABUPATEN BURU, MALUKU \\ (Isolation of Mercury Resistance Bacteria from Gold Mining Waste in Buru District, Maluku)
}

\author{
Rosita Mangesa* dan Kasmawati \\ ${ }^{1}$ Prodi Pendidikan Biologi, Fakultas Keguruan dan Ilmu Pendidikan, Universitas Iqra Buru \\ Jalan Prof. Dr. Abd. Bassalamah, M.Si, Namlea, Kabupaten Buru, Maluku, 97571. \\ *Penulis korespondensi. Tel: 082238176983. Email: rositamangesa5@ gmail.com.
}

Diterima: 19 Juli 2019

Disetujui: 28 September 2019

\begin{abstract}
Abstrak
Pulau Buru merupakan salah satu pulau penambangan emas dan banyak dilakukan secara illegal dengan melibatkan penggunaan merkuri untuk alat bantu dalam proses ekstraksi emas melalui proses amalgamasi. Merkuri merupakan bahan kimia yang berbahaya dan bersifat toksik bagi manusia dan juga lingkungan, dan dampak dari penggunaan merkuri ini telah dirasakan oleh masyarakat setempat. Penelitian ini bertujuan untuk memperoleh bakteri yang resisten terhadap merkuri sehingga dapat digunakan dalam proses bioremediasi. Penelitian ini merupakan penelitian skala laboratorium dan dianalisis secara deskriptif. Hasil penelitian ini yaitu dari kedua lokasi pengambilan sampel diperoleh 17 isolat dengan morfologi yang berbeda-beda serta dari ke-17 isolat tersebut resisten terhadap merkuri.
\end{abstract}

Kata kunci: isolasi, bakteri resisten, merkuri, limbah, tambang emas.

\begin{abstract}
Buru Island is one of the gold mining islands and much of them are illegally that used mercury in gold extraction using uses mercury. Mercury is a chemical that is harmful and toxic to humans as well as the environment, and recently the impact of mercury use has been found by the local community. This study aims to obtain bacteria that are resistant to mercury so that it can be used in the bioremediation process. This research is a laboratory scale research and analyzed descriptively. The results of this study, namely from the two sampling locations obtained 17 isolates with different morphologies and from the 17 isolates were resistant to mercury.
\end{abstract}

Keywords: isolation, resistant bacteria, mercury, waste, gold mining.

\section{PENDAHULUAN}

Merkuri (Hg) merupakan salah satu jenis logam berat yang membahayakan bagi kesehatan manusia, baik dalam dosis tinggi maupun rendah. Merkuri bersifat neurotoksin sehingga dapat menyebabkan kerusakan pada ginjal, sistem saraf, pernafasan, kardiovaskular, gastrointestinal, sistem imun, hati dan reproduksi, namun masih banyak masyarakat yang menggunakan merkuri khususnya dibidang pertambangan untuk memurnikan logam dan menghasilkan emas murni.

Kabupaten Buru merupakan salah satu daerah di Maluku yang mengalami masalah kesehatan akibat dari penambangan emas tradisional yang menggunakan merkuri dan sianida pada proses amalgamasi. Berdasarkan hasil riset berbagai sungai disekitar gunung botak telah tercemar merkuri seperti Sungai Suket, Sungai Waetina, Sungai Kayeli, Sungai Anhony, Sungai Wailata. Di Kabupaten Buru, selain Gunung Botak terdapat daerah lain yakni Gogorea yang juga merupakan tempat penambangan yang mana pada umumnya masyarakat menggunakan merkuri untuk proses amalgamasi. Sejauh ini belum ada penangan khusus dalam mengatasi limbah merkuri, karena pada umumnya para penambang hanya mengendapkan limbah sebelum dibuang. Hasil endapan dari limbah tidak serta merta mengurangi zat pencemar sehingga dibutuhkan penanganan khusus, jika tidak hasil endapan akan mempengaruhi lingkungan maupun kesehatan makhluk hidup yang berada disekitar penambangan.

Pada umumnya untuk mendapat emas para Penambangan Skala Kecil (PSK) menumbuk urat kuarsa yang mengandung biji emas dan digiling menggunakan trommel hingga berbentuk pasir yang kemudian diolah dengan teknik amalgamasi. Penggunaan merkuri memiliki dampak yang sangat besar bagi lingkungan maupun kesehatan masyarakat apabila limbah merkuri tidak diolah dan langsung dibuang kelingkungan. Untuk mengatasi dampak dari limbah merkuri dibutuhkan proses bioremediasi. Pembuangan sisa limbah penamambangan secara sembarangan akan menyebakan pencemaran lingkungan dan 
menimbulkan berbagai macam penyakit dan pengobatan dengan menggunakan antibiotik secara bebas dan terus menerus dapat pula menyebabkan resisten pada tubuh. Beberapa bakteri diketahui resisten pada merkuri, seperti yang diteliti di kawasan perairan seperti kawasan perairan di tambang emas di Sekadau Kalimantan (Abdullah dkk, 2018), kawasan penambangan di Poboya Sulawesi Tengah (Kanzil dkk 2015) dan di kawasan Malalayang Sulawesi Utara (Pattuju dkk, 2014). Kontaminasi $\mathrm{Hg}$ diketahui telah terjadi pada kasus di wilayah Krueng Sabee, Provinsi Aceh, di mana telah diteliti bahwa $\mathrm{Hg}$ dijumpai keberadaannya pada air minum dan juga ditemui pada sampel ikan dan rambut kepala manusia (Sofia dan Husodo, 2016). Selain pada kawasan perairan, pada kasus lain ditemukan bakteri yang resisten merkuri yang diisolasi dari plak gigi (Abdullah dkk, 2018).

Hasil riset yang dialakukan oleh Salatutin dkk, (2015) dan Rumatoras dkk, (2016) menunjukan bahwa sungai Waeapo yang berada di pulau Buru telah terkontaminasi merkuri, bahkan hingga rambut dari penduduk desa Kayeli ditemukan konsentrasi merkuri sebesar 0,10-3,25 ppm. Untuk mencegah bahaya yang ditimbulkan oleh pencemaran logam berat merkuri telah banyak dilakukan melalui riset baik secara buatan maupun alami dengan bantuan mikroorganisme berupa bakteri yang dikembangkan melalui mikrobiologi terapan dan biologi melekuler. Kedua cabang ilmu tersebut merupakan penggagas utama dalam upaya pengembangan teknologi bioremediasi menggunakan agen pengurai limbah merkuri.
Bioremediasi merupakan cara untuk memperbaiki kualitas lingkungan menjadi lingkungan yang lebih stabil serta memiliki daya dukung dengan memanfaatkan aktivitas dari makhluk hidup pada tingkat seluler sebagai agen untuk mengubah komponen bahan pencemar lingkungan yang berbahaya menjadi tidak berbahaya. Penggunaan bakteri dalam proses bioremediasi sudah cukup banyak yang memberikan hasil positif, dalam hal bakteri mampu mengurai senyawa-senyawa yang berbahaya menjadi senyawa yang lebih sederhana, dengan begitu zat pencemar yang terdapat pada limbah dapat menurun.

Proses pengubahan merkuri yang memiliki sifat toksik menjadi non toksik dapat dilakukan oleh bakteri yang memiliki kemampuan resistensi terhadap merkuri dengan adanya gen mer operon. Untuk memperoleh bakteri yang resistensi terhadap merkuri data dilakukan dengan mengisolasi bakteri dari sampel yang terpapar merkuri, melalui penelitian ini diharapkan dapat memperoleh bakteri yang bersifat resistensi sehingga dapat dikembangkan untuk proses bioremediasi.

\section{METODE PENELITIAN}

\section{Waktu dan Lokasi}

Penelitian ini dilaksanakan pada bulan April Juli 2019, dan dilaksanakan di Laboratorium MIPA Universitas Pattimura Ambon. Pengambilan sampel penelitian diambil dari limbah penambangan emas daerah Gunung Botak dan Gunung Gogorea Kabupaten Buru (Gambar 1).

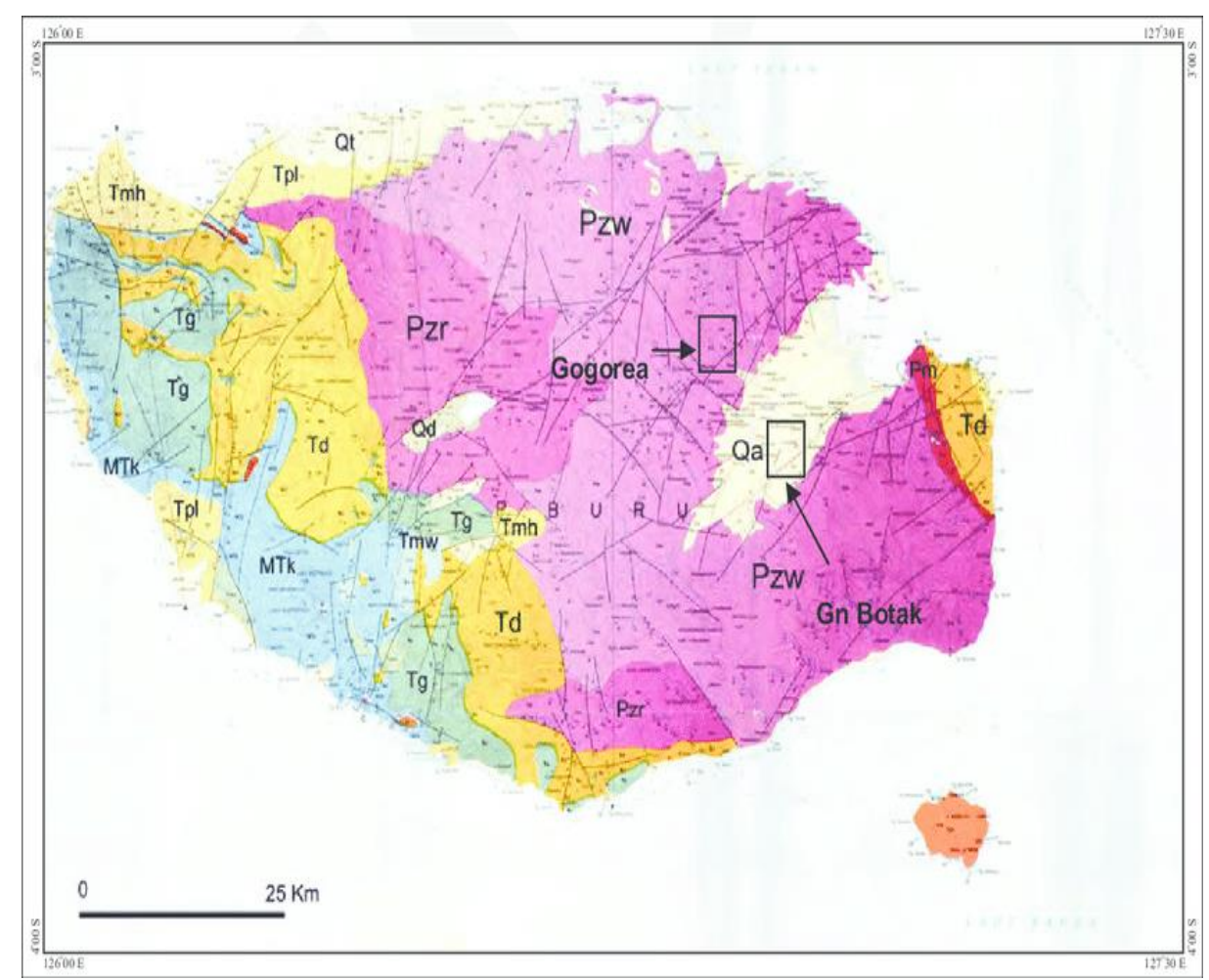

Gambar 1. Lokasi pengambilan sampel penelitian daerah Gunung Botak dan Gunung Gogorea 


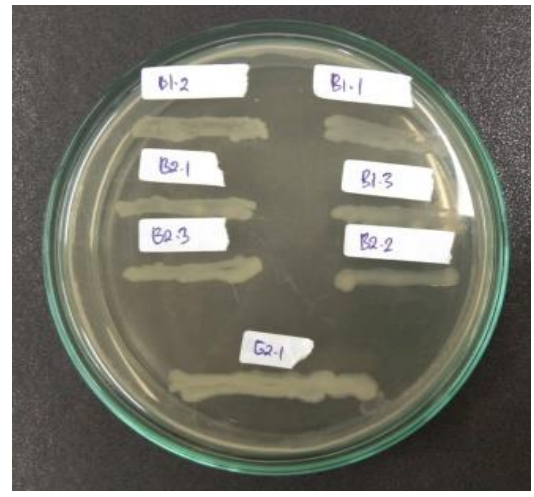

(a)

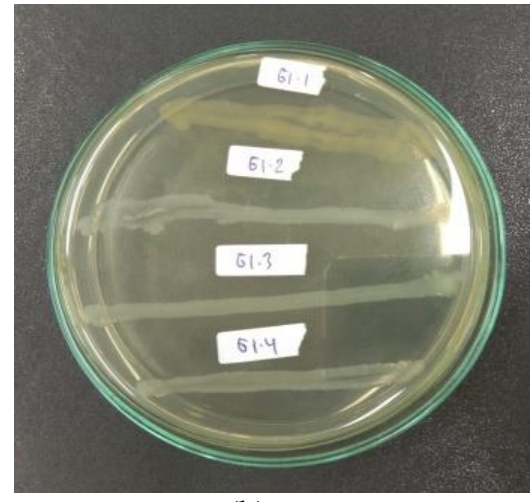

(b)

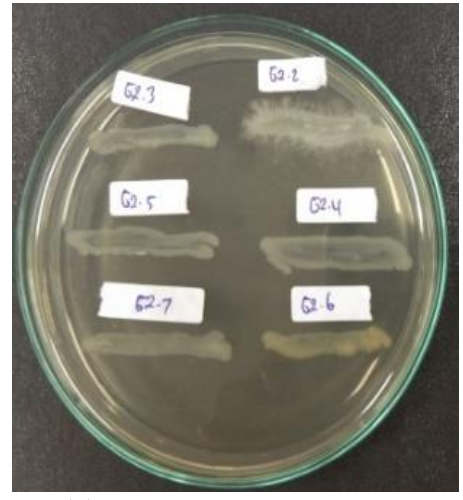

(c)

Gambar 1. Hasil foto pengamatan morfologi koloni bakteri (a). sampel B1 \& B2, (b). sampel G1, dan (c). sampel G2.

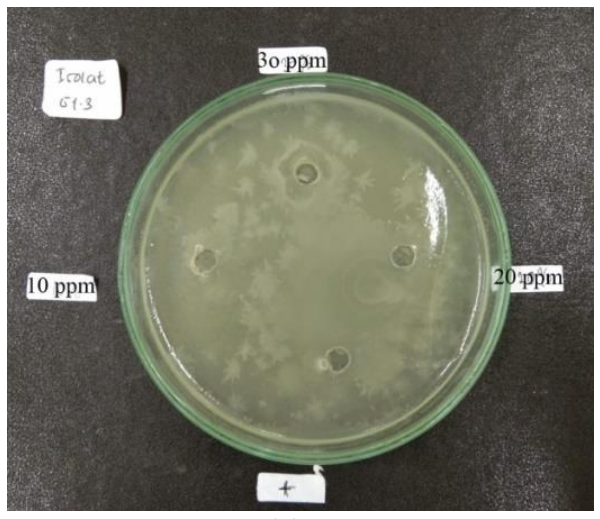

(a)

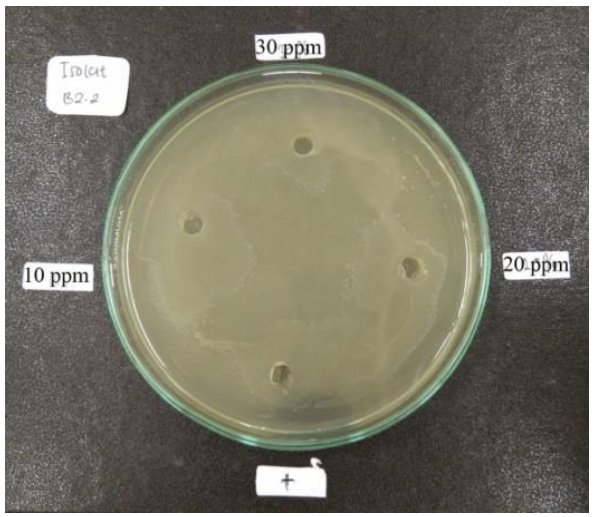

(b)

Gambar 2. Zona hambat isolat (a). G1.3 dan (b). B2.2.

\section{Prosedur}

Penelitian ini merupakan penelitian skala laboratorium dengan pendekatan kualitatif deskriptif, untuk memperoleh data primer mengenai isolat bakteri yang bersifat resistensi terhadap merkuri dari kedua sampel yang akan diteliti, dengan prosedur sebagai berikut. Sampel dari Gunung Botak dan Gunung Gogorea ditampung sebanyak $250 \mathrm{~mL}$ yang selanjutnya dimasukkan kedalam botol reagen gelap yang kemudian dibawa ke Laboratorium Mikrobiologi Universitas Pattimura. Selanjutnya, sebanyak $50 \mathrm{~mL}$ sampel dari tiap botol diambil dan dicampur ke dalam botol yang masing-masing berisi $450 \mathrm{~mL}$ Nutrient Broth, dan dipropagasi dengan suhu kamar selama 5 hari, selanjutnya isolasi bakteri.

Isolasi bakteri dibutuhkan media seleksi yaitu Nutrient Agar yang selanjutnya ditambahkan $\mathrm{HgCl} 230 \mathrm{ppm}$, dengan menggunakan metode pour plate dari pengenceran bertingkat $10^{-3}-10^{-5}$. Bakteri yang dominan tumbuh selanjutnya dimurnikan kembali dengan media NA - $\mathrm{HgCl} 230 \mathrm{ppm}$, dan tiap koloni yang telah diperoleh dideskripsikan morfologinya dan dilanjutkan dengan pengujian sensitivitas bakteri.

Pengujian sensitivitas bakteri terhadap mercury dilakukan dengan menggunakan cup-plate technique (metode sumuran), yang mana masingmasing bakteri yang telah disuspensikan ke dalam $\mathrm{NaCl}$ pada tingkat kekeruhan $1 \mathrm{McF}$ yang digoreskan pada media Mueller Hinton Agar serta dibuatkan 4 buah sumuran yang masing-masing diberi $\mathrm{HgCl}_{2} 30,20$ dan $10 \mathrm{ppm}$, serta aquades sebagai kontrol positif. Bakteri yang bersifat resistensi akan dilanjutkan ke tahap identifikasi.

\section{HASIL DAN PEMBAHASAN}

Berdasarkan hasil penelitian yang telah dilakukan, maka didapatkan hasil bahwa dari kedua lokasi sampel penelitian yang mana satu lokasi diambil dua sampel sehingga total sampel menjadi empat.

\section{Isolasi dan Identifikasi Bakteri dari Sampel}

$\mathrm{Ke}$ empat sampel yang telah dianalisis dipeoleh 17 isolat dengan ciri morfologi yang berbeda. Adapun perbedaan penampakan koloni ketika ditumbuhkaan pada media pertumbuhan merupakan karakter yang berguna sebagai dasar untuk membedakan bakteri. Ciri-ciri morfologi koloni dari 17 isolat dapat dilihat pada Gambar 2. Dari hasil foto pengamatan morfologi koloni bakteri akan dijabarkan melalui Tabel 1 . 
Tabel 1. Pengamatan makroskopis morfologi koloni.

\begin{tabular}{|c|c|c|c|c|c|c|}
\hline No & $\begin{array}{l}\text { Kode } \\
\text { isolat }\end{array}$ & Warna & Bentuk & Margin & Elevasi & Ukuran \\
\hline 1. & B1.1 & Putih susu & Bundar & Licin & Datar & Sedang \\
\hline 2. & B 1.2 & Kuning Muda & Bundar & Berombak & Datar & Sedang-besar \\
\hline 3. & B 1.3 & Putih susu & Bundar & Licin & Timbul & Kecil-sedang \\
\hline 4. & B2.1 & Putih susu & Bundar & Licin & Timbul & Kecil-sedang \\
\hline 5. & B2.2 & Putih susu & Bundar & Licin & Timbul & Kecil-sedang \\
\hline 6. & B2.3 & Putih susu & Bundar & Berombak & Timbul & Sedang \\
\hline 7. & G1.1 & Kuning & Bundar & Licin & Timbul & Kecil \\
\hline 8. & $\mathrm{G} 1.2$ & Putih susu & Bundar & Licin & Timbul & Kecil \\
\hline 9. & $\mathrm{G} 1.3$ & Putih susu & Bundar & Licin & Timbul & Kecil \\
\hline 10. & G1.4 & Putih susu & Bundar & Licin & Timbul & Kecil-sedang \\
\hline 11. & $\mathrm{G} 2.1$ & Putih susu & Berbenang-benang & Bercabang & Datar & Sedang-besar \\
\hline 12. & $\mathrm{G} 2.2$ & Putih susu & Bundar dengan tepian kerang & Sikat & Datar & Besar \\
\hline 13. & $\mathrm{G} 2.3$ & Putih susu & Bundar & Berombak & Datar & Kecil-sedang \\
\hline 14. & $\mathrm{G} 2.4$ & Putih susu & Bundar & Licin & Timbul & Sedang-besar \\
\hline 15. & $\mathrm{G} 2.5$ & Putih susu & Bundar & Licin & Timbul & Sedang-besar \\
\hline 16. & $\mathrm{G} 2.6$ & Kuning muda & Bundar & Licin & Datar & Kecil \\
\hline 17. & $\mathrm{G} 2.7$ & Putih susu & Bundar & Licin & Timbul & Kecil-sedang \\
\hline
\end{tabular}

Secara keseluruhan isolat bakteri memperlihatkan bentuk yang sama yaitu bentuk bundar kecuali isolat G2.1 yang berbentuk berbenang-benang dan isolate G2.2 yang berbentuk bundar dengan tepian kerang. Margin atau tepian isolat mayoritas licin terkecuali isolat B1.2, B2,3 dan G2.3 margin berbentuk berombak, isolat G2.1 marginnya bercabang sedangkan G2.2 marginnya berbentuk sikat. Elevasi dari isolat mayoritas berbentuk timbul dan datar sedangkan ukuran dari kecil hingga sedang.

\section{Bakteri Resistensi Merkuri}

Berdasarkan penelitian yang telah dilakukan, diperoleh hasil bahwa keseluruhan isolat memiliki potensi sebagai bakteri pendegradasi merkuri yang dibuktikan dengan kemampuan tumbuh pada pada perlakuan dengan kadar konsentrasi merkuri sebesar 10, 20 dan $30 \mathrm{ppm}$ tidak ditemukannya zona bening $(0 \mathrm{~mm})$. Hal ini terlihat pada Gambar 2 dan Tabel 2.

Berdasarkan hasil pengukuran terhadap diameter daya hambat bakteri pendegradasi merkuri terlihat bahwa keseluruhan isolat mempu menjadi bakteri pendegradasi merkuri. Hal ini terlihat dari bakteri yang mampu tumbuh pada cekaman konsentrasi merkuri yang berbeda dengan tidak ditemukannya zona bening. Penyebab hal tersebut adalah karena adanya gen resisten merkuri pada setiap isolat. Gen resisten ini biasanya dipengaruhi oleh adanya aktivitas respon bakteri berupa adaptasi terhadap lingkungan sehingga gen yang terekpresikan adalah gen resisten. Cara kerja dari gen resisten merkuri (mer operon) yaitu mengubah $\mathrm{Hg}^{2+}$ yang bersifat toksik menjadi bentuk $\mathrm{Hg}^{0}$ yang memiliki sifat volatile, dengan demikian bakteri masih dapat tumbuh di dalam merkuri.
Tabel 2. Hasil pengukuran diameter zona bening (mm) sebagai indikator bakteri resistensi merkuri.

\begin{tabular}{llllll}
\hline No & Kode & \multicolumn{4}{c}{ Diameter zona bening $(\mathrm{mm})$} \\
\cline { 3 - 6 } & isolat & kontrol & $10 \mathrm{ppm}$ & $20 \mathrm{ppm}$ & $30 \mathrm{ppm}$ \\
\hline 1. & B1.1 & 0 & 0 & 0 & 0 \\
2. & $\mathrm{B} 1.2$ & 0 & 0 & 0 & 0 \\
3. & $\mathrm{B} 1.3$ & 0 & 0 & 0 & 0 \\
4. & $\mathrm{B} 2.1$ & 0 & 0 & 0 & 0 \\
5. & $\mathrm{B} 2.2$ & 0 & 0 & 0 & 0 \\
6. & $\mathrm{B} 2.3$ & 0 & 0 & 0 & 0 \\
7. & $\mathrm{G} 1.1$ & 0 & 0 & 0 & 0 \\
8. & $\mathrm{G} 1.2$ & 0 & 0 & 0 & 0 \\
9. & $\mathrm{G} 1.3$ & 0 & 0 & 0 & 0 \\
10. & $\mathrm{G} 1.4$ & 0 & 0 & 0 & 0 \\
11. & $\mathrm{G} 2.1$ & 0 & 0 & 0 & 0 \\
12. & $\mathrm{G} 2.2$ & 0 & 0 & 0 & 0 \\
13. & $\mathrm{G} 2.3$ & 0 & 0 & 0 & 0 \\
14. & $\mathrm{G} 2.4$ & 0 & 0 & 0 & 0 \\
15. & $\mathrm{G} 2.5$ & 0 & 0 & 0 & 0 \\
16. & $\mathrm{G} 2.6$ & 0 & 0 & 0 & 0 \\
17. & $\mathrm{G} 2.7$ & 0 & 0 & 0 & 0 \\
\hline
\end{tabular}

Hasil penelitian menunjukan bahwa keseluruhan isolat bahkan mampu tumbuh pada konsentrasi merkuri 30 ppm, dengan demikian keseluruhan isolat memiliki gen merA dan gen merB yang mana keseluruhan isolat tersebut merupakan bakteri resisten merkuri spectrum luas. Hal ini sejalan dengan pendapat Tanumiharja dkk (2017) dalam penelitiannya yang menyatakan bahwa suatu bakteri dikatan sebagai bakteri resisten merkuri jika bakteri tersebut dapat hidup dalam kadar merkuri $\left(\mathrm{HgCl}_{2}\right) 5 \mathrm{ppm}$ pada media nutrient agar. Bakteri yang mampu hidup di lingkungan yang mengandung merkuri $\left(\mathrm{HgCl}_{2}\right)$ dengan kadar $20 \mathrm{ppm}$ atau lebih dapat digolongkan dalam bakteri resistensi merkuri tinggi. Selain itu bakteri yang hanya memiliki gen merkuri reduktase (merA) disebut bakteri resistensi merkuri spektrum sempit, 
sedangkan bakteri yang memiliki gen merA dan gen merB merupakan bakteri resistensi merkuri spektrum luas. Identifikasi jenis bakteri yang ditemukan di Kabupaten Buru ini masih perlu penelitian lebih lanjut.

Suryani (2011) menyebutkan bahwa beberapa bakteri bekerja secara aerobik dan fakultatif untuk mengkatalisasi proses reduksi $\mathrm{Hg}(\mathrm{II})$ menjadi $\mathrm{Hg}(0)$. Contoh bakteri ini adalah Bacillus, Pseudomonas, Corynebacterium, Micrococcus dan Vibrio. Pseudomonas maltophilia dapat mereduksi $\mathrm{Cr}^{6+}$ yang bersifat mobile dan toksik menjadi bentuk immobile dan nontoksik $\mathrm{Cr}^{3+}$ serta meminimumkan mobilitas ion toksik lainnya di lingkungan seperti $\mathrm{Hg}^{2+}, \mathrm{Pb}^{2+}$ dan $\mathrm{Cd}^{2+}$. Keberadaan bakteri isolat yang tahan di dalam air ini dapat dikembangkan lebih lanjut dalam rangka upaya pengolahan air limbah tambang emas yang mengandung $\mathrm{Hg}$. Hal ini juga serupa dengan upaya yang diteliti oleh Suharno dkk (2014) yang mengembangkan mikoriza arbuskula untuk upaya rehabilitasi lahan di kawasan tailing tambang emas Timika.

\section{KESIMPULAN}

Hasil isolasi bakteri dari sampel limbah hasil penambangan di Gunung Botak dan Gogorea, diperoleh 17 isolat dengan karakteristik morfologi yang berbeda-beda, serta dari ke-17 isolat tersebut memiliki kemampuan mendegradasi merkuri berdasarkan hasil pengamatan zona bening.

\section{UCAPAN TERIMAKASIH}

Penulis menyampaikan ucapan terima kasih kepada Universitas Iqra Buru yang menjalin kerjasama dengan Kementrian Riset, Teknologi dan Pendidikan Tinggi yang telah mendanai penelitian ini melalui Penelitian Dosen Pemula.

\section{DAFTAR PUSTAKA}

Abdullah., Luqman, H., Fitriandi, E. dan Rahmawati, 2018. Deteksi Keberadaan Bakteri Resisten Logam Merkuri (Hg) Pada Penambangan Emas Tanpa Izin (Peti) Di Simpi, Sekadau, Kalimantan Barat. Indonesian Journal of Pure and Applied Chemistry, $1(2): 56-61$.
Kanzil, T., Fatimawali dan Manampiring, A., 2015. Uji Resistensi Bakteri Bacillus sp yang Diisolasi dari Plak Gigi Terhadap Merkuri dan Eritromisin. Jurnal e-Biomedik, 3(1):80-83.

Pangestu, R., Gulli, M., dan Miswan, M., 2014. Deteksi Bakteri Resistensi Merkuri Pada Areal Tromol Pertambangan Emas Kelurahan Poboya Provinsi Sulawesi Tengah. Biocelebes, 8(1):1-9.

Pattuju, S.M., Fatimawali dan Manampiring, A., 2014. Identifikasi Bakteri Resistensi Merkuri Pada Urine, Feses dan Kalkulus Gigi Pada Individu di Kecamatan Malalayang, Manado, Sulawesi Utara. Jurnal e-Biomedik, 2(2):532540.

Rumatoras, H., Taipabu, M.I., Lesiela, L., dan Male Y.T., 2016. Analysis of Mercury (Hg) Content on Hair Villagers Kayeli, Ilegal Gold Mining Result in Botak Mountain Area, Buru Regency-Maluku Province. Ind. J. Chem. Res., 3(2):290-294

Salatutin, F.M., Batawi, C.Y., Lessil, C.Y., dan Male, Y.T., 2015. Analysis of Mercury (Hg) Distribution in The Waeapo River Irrigation Area, Buru Regency, Maluku Province, Gold Mining Without Permission Result in Botak Mountain Area. Ind. J. Chem. Res., 3(1):270276.

Sofia, S., dan; Husodo, A.H., 20176. Kontaminasi Merkuri Pada Sampel Lingkungan dan Faktor Risiko Pada Masyarakat dari Kegiatan Penambangan Emas Skala Kecil Krueng Sabee Provinsi Aceh. J. Manusia \& Lingkungan, 23 (3):310-318.

Suharno, Sancayaningsih, R.P., Sutariningsih, E.S, dan Kusmandari, R.K., 2014. Keberadaan Fungsi Mikoriza Arbuskula di Kawasan Tailing Tambang Emas Timika Sebagai Upaya Rehabilitasi Lahan Ramah Lingkungan. $J$. Manusia \& Lingkungan, 21(3):295-303.

Suryani, Y., 2011. Bioremediasi Limbah Merkuri dengan Menggunakan Mikroba Pada Lingkungan yang Tercemar. Jurnal Istek, 5:12.

Tanumihardja C. A. N., Kepel Billy., Bodhi Widhi. 2017. Identifikasi Bakteri Resistensi Merkuri Menggunakan Metode 16SrRNA Terhadap Plak Gigi Pada Pasien Pengguna Tumpatan Amalgam. Jurnal e-Biomedik, 5(2):1-6. 